\title{
Longitudinal Changes in the Eating Habits of Patients with Cancer Receiving Palliative Care
}

\section{Hastalık Sürecinde Palyatif Bakım Hastalarında Yeme Alışkanlığı Değişimi}

\author{
(D) Nagihan Yıldız ÇELTEK¹, iD Ufuk ÜNLÜ11, id Rıza ÇITIL², id Yalçın ÖNDER², iD Mustafa SÜREN³ , id İsmail OKAN4 \\ ${ }^{1}$ Tokat Gaziosmanpaşa University Faculty of Medicine, Department of Family Medicine, Tokat, Turkey \\ ${ }^{2}$ Tokat Gaziosmanpaşa University Faculty of Medicine, Department of Public Health, Tokat, Turkey \\ ${ }^{3}$ Tokat Gaziosmanpaşa University Faculty of Medicine, Department of Anesthesia and Reanimation, Tokat, Turkey \\ ${ }^{4}$ Tokat Gaziosmanpaşa University Faculty of Medicine, Department of General Surgery, Tokat, Turkey
}

\section{ABSTRACT}

Objective: Nutritional changes are frequently observed in patients with cancer because of multiple symptoms. This study aimed to determine food types most preferred by the patients and most suitable to them and to identify methods to enrich these food options in the future.

Methods: This cross-sectional, descriptive study was conducted on 151 patients at Tokat Gaziosmanpaşa University Palliative Care Center. Demographic data, nutritional habits, and food preferences were obtained using a questionnaire. The Karnofsky performance scale (KPS) was also used.

Results: Of the 151 patients, $53.6 \%(\mathrm{n}=81)$ were male, and the mean patient age was $62.7 \pm 14.7$ years. Moreover, $47 \%(n=71)$ of the patients were bothered by the food odor; specifically, $27.8 \%$ reported that the food had a disturbing smell. The average KPS score was $63.9 \pm 15.0$ points. The mean KPS scores were significantly higher in the eating group ( $\mathrm{p}=0.043$ ). Patients most preferred yayla $(39.7 \%)$ among soups and yogurt $(28.8 \%)$ among milk products. Only $36.4 \%(n=55)$ of the patients stated that they could continue to use enteral nutrition products at the recommended dosage regularly, but $38 \%(n=21)$ have been consuming enteral nutrition products.

\section{ÖZ}

Amaç: Çeşitli semptomlar nedeniyle kanser hastalarında beslenme değişiklikleri sıklıkla görülür. Bu çalışmayı hastalarımız tarafından en çok tercih edilen, onlar için en uygun gıda seçeneklerini ve bu seçenekleri gelecekte nasıl zenginleştirebileceğimizi belirlemek amacıyla planladık.

Yöntemler: Kesitsel ve tanımlayıcı tipteki bu çalışma Tokat Gaziosmanpaşa Üniversitesi Palyatif Bakım Merkezi'ndeki 151 hasta üzerinde gerçekleştirilmiştir. Demografik veriler, beslenme alışkanlıkları ve gıda tercihleri verileri anket ile elde edildi. Karnofsky Performans Ölçeği katılımcılara aynı anda uygulanmıştır.

Bulgular: Toplam 151 hastanın \%53,6's1 (n=81) erkekti ve hastaların yaş ortalaması $62,7 \pm 14,7$ idi. Hastaların \% $\%$ 's $\operatorname{sinin}(n=71)$ kokudan rahatsız olduğu ve özellikle gıda kokusunun $(\% 27,8)$ hastaları etkilediği bulunmuştur. Karnofsky Performans Ölçeği (KPS) ortalama puanı $63,9 \pm 15,0$ olarak tespit edildi. Ortalama KPS puanları yemek yiyebilen grupta anlamlı olarak yüksekti ( $\mathrm{p}=0,043)$. Çorba çeşitlerinden yayla çorbası $(\% 39,7)$, süt ürünleri çeşitlerinden yoğurt $(\% 28,8)$ hastalar tarafindan en çok tercih edilen gidalardı. Hastaların yalnızca \%36,4'ü $(n=55)$ enteral beslenme ürünlerini düzenli olarak, önerilen dozda kullanmayı sürdürebileceklerini, ancak bu hastaların dahi yalnızca \%38'i $(n=21)$ enteral ürünleri severek tükettiklerini ifade etmişlerdir.

Address for Correspondence: Ufuk ÜNLÜ, Tokat Gaziosmanpaşa University Faculty of Medicine, Department of Family Medicine, Tokat, Turkey

E-mail: drufukunlu@gmail.com ORCID ID: orcid.org/0000-0001-7995-0866 
Conclusion: When offering healthy food options, patients should have sufficient calorie intake and consume foods that they think are delicious. Starting enteral nutrition products early is recommended to avoid malnutrition.

Keywords: Palliative care, eating habits, food preferences
Sonuç: Hastalara sağlıklı gıda seçenekleri sunmaya çalışırken, yeterli kalori aldıklarından emin olmak ve lezzetli olduğunu düşündükleri yiyecekleri tüketmelerine yardımcı olmak önemlidir. Hastalarda malnütrisyondan kaçınmak için enteral beslenme ürünlerine başlamada geç kalınmaması gerektiğini düşünüyoruz.

Anahtar Sözcükler: Palyatif bakım, yeme alışkanlıkları, gıda tercihleri

\section{Introduction}

Palatal delight, food preferences, and diet patterns of patients change during cancer treatment (1). Many patients with cancer experience significant weight changes according to the type and stage of the tumor. Oral feeding is diminished or completely stopped because of various factors like smell or taste changes, loss of appetite, nausea, vomiting, dysphagia, mouth sores, and pain (2). The anorexia-cachexia syndrome in cancer is a clinical state characterized by decreased appetite, weight loss, metabolic disorders, and inflammatory events. The etiology of anorexia in cancer is unknown. However, it causes performance loss, decreases quality of life, and results in high morbidity and mortality rates (3).

Studies have reported impaired taste function and reduction in flavor perception in patients with cancer. Malnutrition leads to impaired immune function and failure to cope with the physical stress of radiotherapy, chemotherapy, and surgery, so treatment procedures are interrupted. Many studies have focused on the prevention of malnutrition (4). To maintain the optimal health level of patients with cancer, diet regimens are changed according to their preferences $(3,4)$. Many nutritional support products were created for specific patients. However, the consumption of these products is sometimes extremely difficult because patients developed a high sensitivity to odor and experienced changes in taste perception (5).

This study aimed to understand the food preferences, feeding habits, and attitudes of patients with cancer receiving palliative care related to nutrition.

\section{Methods}

This cross-sectional and descriptive study was conducted on patients with cancer receiving palliative care, between April and November 2016. In our university, palliative care started in 2010 as a voluntary group (palliative care study group) comprising of professionals from different disciplines including surgical oncology, internal medicine, family medicine, public health and nurses, social workers, dieticians, and psychologists.

Initially, the palliative care center accepted patients in the outpatient clinic in November 2015 and started to provide inpatient care in November 2017. The palliative care study group met regularly once a week and organize multidisciplinary research, education, and patient care. The palliative care center is under the responsibility of a family practitioner together with a nurse. Other disciplines were consulted during the treatment when needed.

Ethical committee approval was obtained before the study (16KAEK-088). Patients aged $>18$ years with cancer diagnosis followed in our palliative care unit and agreed to participate in the study were included in the study. Patients aged $<18$ years who had mental illnesses, communication difficulties, and malignant bowel obstruction and were not unwilling to participate in the study were excluded.

A questionnaire was developed to elucidate the feeding habits of patients receiving palliative care by the palliative care study group during several meetings. First, the themes were identified until redundancy. Then, the themes were reduced and related questions were formed. The answer styles and answers were created. The questionnaire consisted of three parts that contain 15 open-ended questions assessing the demographic data of the patients, two open-ended questions and 13 close-ended questions assessing nutritional habits, and six Likert-type questions assessing food preferences. The questions were revised after a pilot test was applied to 20 patients who had similar characteristics with the target group in the palliative care center. Tools used in our palliative care unit such as the Karnofsky performance scale (KPS), Katz daily living activities scale, and basic daily living activities scale were completed during the first admission by a palliative care doctor. The questionnaire was delivered by a service secretary in the outpatient unit and completed in $20 \mathrm{~min}$ by face-to-face interview method.

\section{Statistical Analysis}

Descriptive statistics were presented as mean, standard deviation, median, percentile $25(\mathrm{Q} 1)$, percentile $75(\mathrm{Q} 3)$, and minimum and maximum values for numerical variables. The conformity of the variables to normal distribution was examined by using Kolmogorov-Smirnov/Shapiro-Wilk tests. The chi-square test was used for binary and multiple comparisons between categorical variables. The Mann-Whitney $U$ test was used in binary group comparisons of variables that did not disperse normally. Data were analyzed with SPSS v20 software package (IBM Corp., Armonk, NY, USA). For evaluation of demographic data, descriptive statistics (such as percentage, average, standard deviation) were used, and chi-square and Student's t-test were used for comparisons between groups. $\mathrm{P}<0.05$ was considered significant. 


\section{Results}

\section{Demographic and Clinical Features of Patients}

A total of 151 patients were included in the study, of which 53\% $(\mathrm{n}=81)$ were male. The mean age was $62.7( \pm 14.7)$ years. Details of the demographic features are presented in Table 1 .

The most common cancer diagnoses were gastrointestinal tumors. In addition, 119 (78.8\%) patients had decreased weight, and $38.7 \%(n=46)$ stated that they had lost $\geq 10 \mathrm{~kg}$ during the disease period. The mean KPS score was $63.9( \pm 15.0)$ points. As regards the disease duration after diagnosis, $57 \%$ of the patients had a disease duration of $<1$ year. Regarding treatment, 94 $(62.3 \%)$ and $70(46.4 \%)$ patients received chemotherapy and radiotherapy, respectively.

\section{Nutritional Status}

The questionnaire on the nutritional habits of the patients showed that $94.7 \%(n=143)$ were able to eat, 68.2\% $(n=103)$ could not enjoy the food as before, and $36.4 \%(n=55)$ can use enteral nutrition products at the given dose regularly. However,

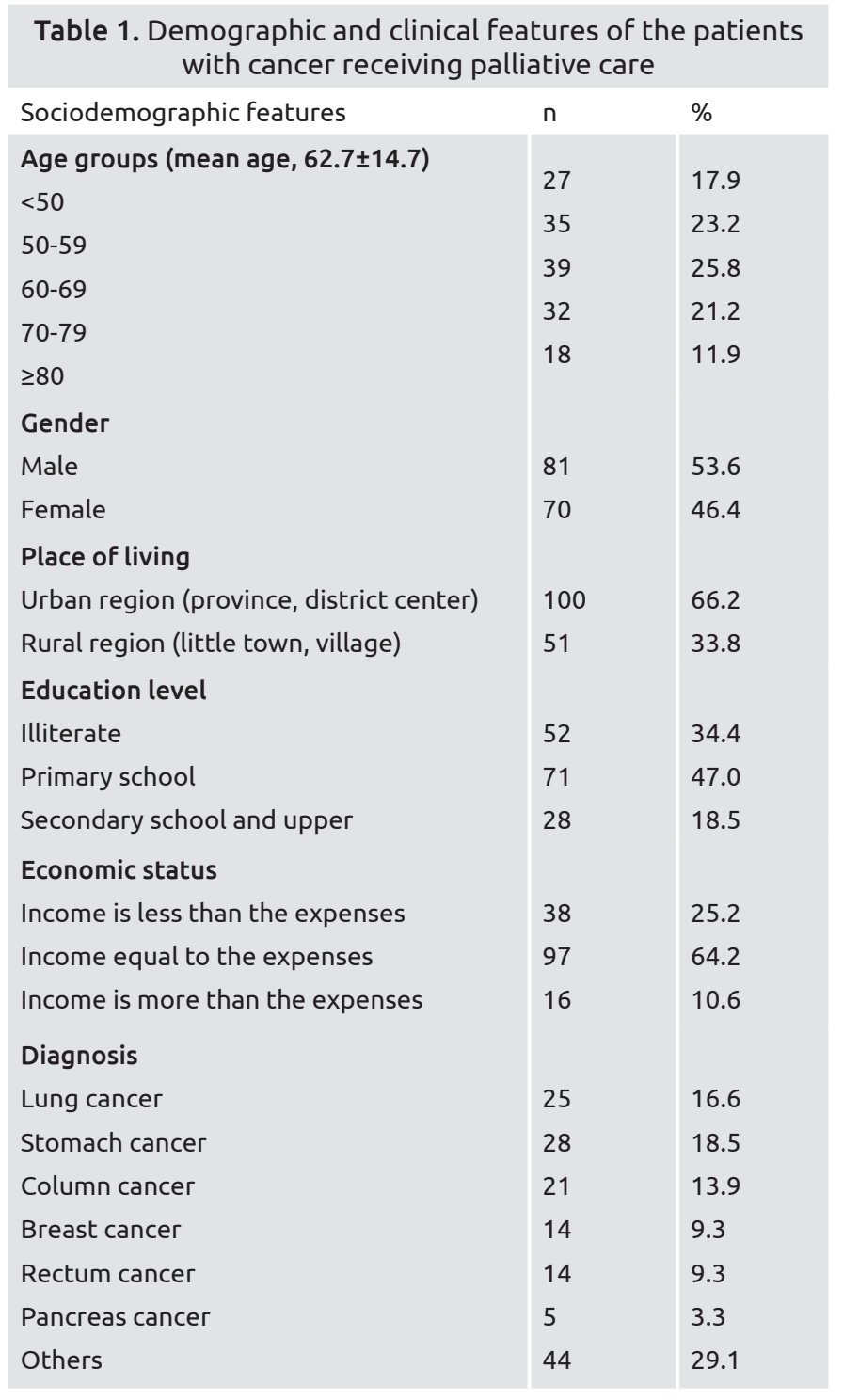

$38 \%(n=21)$ of these patients have been eating the enteral products enjoyably.

In addition, $58.3 \%$ of the patients stated that they managed to complete three meals daily with difficulty. Moreover, $47 \%(n=71)$ of the patients were intolerant to the smell, and $27.8 \%$ reported that the food had a disturbing smell. Furthermore, 98 (64.9\%) patients stated that they could eat for nutritional purposes even though they did not enjoy it. The most common symptoms during cancer diagnosis and treatment were loss of appetite $(62.9 \%)$, nausea and vomiting $(47.7 \%)$, and taste changes (29.8\%). Sour foods (35.1\%) are the most preferred flavor by the patients, and 14 (9.3\%) patients used herbal treatment products for a period after diagnosis.

Patients consumed mostly soup (64.9\%), of which 39.7\% most preferred yayla soup (a regional soup made from yogurt and rice). The food preferences are presented in Table 2.

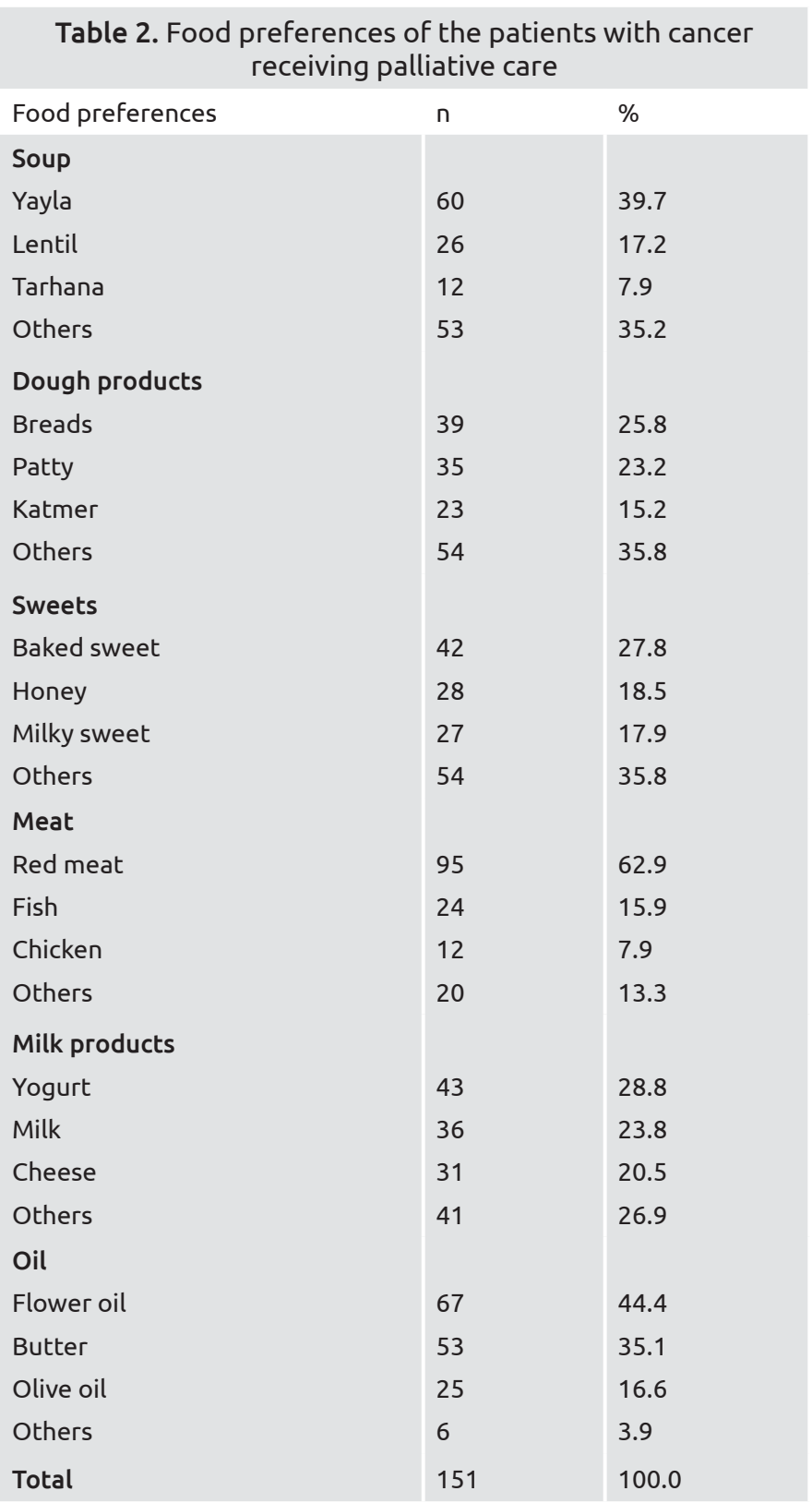




\section{Relationship Between Nutritional Status and KPS Score}

During the interview, most of the patients (94.7\%) were able to eat. The median KPS score of the eating group was significantly higher than that of the non-eating group [60 (60-80) vs. 55 (35$60) ; p=0.043]$. Patients who were dependent on enteral nutrition had significantly lower KPS scores [60 (50-70)]. Significant differences were found between the median KPS scores according to the use of enteral nutrition products (formula) during the treatment (KPS scores [60 (50-70) vs. $70(60-80) ; \mathrm{p}=0.022]$.

\section{Discussion}

This study of patients with cancer in the palliative care unit showed that a large proportion of the patients were able to eat during the study period. Moreover, the majority of the patients had weight loss $>10 \mathrm{~kg}$, and two-thirds did not enjoy food as before. Approximately one-third of the patients were able to consume enteral nutrition products, and only one-third who started the product could have used the given dose regularly. The participants were uncomfortable most with the smell of food. Among the food groups they could consume for nutritional purposes, patients most preferred soup. Regionally, yayla was the most preferred soup. Other frequently preferred foods were bread, baked desserts, meat dish, yogurt, and flower oil.

One of the most common problems in patients with cancer is related to nutrition. Oral feeding of patients is reduced or ceased completely because of symptoms such as nausea, dysphagia, loss of appetite, constipation, mouth sores, and pain. During the initial phases of the disease, loss of appetite and weight loss are observed in one of the two patients, while more than $75 \%$ of the patients experienced these problems in the terminal period, (5) as we also observed in our patients. Enig et al. (1) found that patients experienced anorexia and inadequate nutrition as well as food disgust. The lack of appetite and some other symptoms in patients with cancer might have been caused by malnutrition $(2,6)$. Treatments such as radiotherapy and chemotherapy and the disease process increase the severity of the symptoms and impair the palatal delight of the patients (7). Interestingly, onethird of the patients experienced severely impaired taste sensation. Many authors have investigated the olfactory changes during the progress and treatment of cancer (2,7-11). In the present study, half of the patients had increased odor sensitivity and considered many odors "unbearable or malodorous". Although they were affected by various smells such as cigarettes, detergents, perfumes, and hospital odors, patients are uncomfortable most with food odors. It worsened the nutritional status of the patient since they had already serious problems with eating due to both physical and psychological symptoms such as anorexia and depression. Consequently, malnutrition in patients with cancer, whatever the reason, led to decreased performance, reduced quality of life, and increased morbidity and mortality (3).

We also found a significant relationship between KPS scores and the eating status of the patients. Patients with a high KPS score, which means good physical performance, consume few enteral nutrition products. The possible reason was that formula was started when the general condition of the patient deteriorates or the patient does not use enteral products as long as he/she can consume other foods.

It is extremely important to identify enjoyable foods during this period because leisure experienced during food intake will strong contribute to the well-being of the patients. For the first time, we tried to elucidate in this group of patients (namely, patients with cancer in palliative care) the most preferred food in terms of both taste and nutritional value. Food disgust is frequently seen in patients with cancer receiving active treatment. Dietary regimens are largely altered or allowed to be fed as preferred to maintain the health of these patients at an optimal level $(3,4)$. Our patients preferred soup as food during the diseased state, which quite corresponds with our culture because a strong belief about the nutritional power of soup for diseases is evident in many sayings written in our language, such as "The soup was not asked to the patient-hastaya çorba sorulmaz-, prepare soup for patienthastaya çorba hazırlamak, hasta çorbası-soup for sick". Yayla soup was the most preferred soup, a well-known soup in our country prepared with rice and yogurt. It can be easily prepared and can be potentially enriched with herbs, vegetables, and meat broths. Worldwide, soup is considered an easy meal for patients who experience difficulty with eating. Indeed, Berhardson et al. (7) presented that patients preferred soup more because it can be consumed more easily and quickly. To improve the psychological well-being and nutrition of the patients, the staff in palliative care centers have ordered food and drinks for patients with cancer. However, there is little research on which foods and beverages these patients like during clinical visits (4). In particular, few or no studies have examined the traditional food types preferred by these patients. The sense of taste, i.e., taste perception, is a subject that varies with each person, ethnic origin, and culture and needs to be investigated worldwide. Traditional foods that patients desired need to be evaluated to provide them with food rich in protein, lipid, carbohydrate, and vitamins. The results of these studies will improve the quality of life of patients receiving palliative care, not only because of proper nourishment but also of the ethnic and cultural effects of foods.

As regards feeding management, patients with cancer should receive enough calories while they keep their palatal delight. The food should have a familiar taste and contain nutritious elements to keep up their metabolic balance. The provision of nutritional support, such as enteral feeding solutions, was not considered food intake because they were treated like drugs. Although various taste options with these enteral solutions are present, the patients refuse to drink them, as also shown in our study (5). Therefore; the industrial market tries to overcome the human perception of enteral solutions as well as different taste selections. It is tempting to suggest the enrichment of a well-known, eatable or drinkable, and easily prepared soup with supportive nutritional supplements such as vegetable/meat broths, whey powder, etc., within acceptable changes in the taste. Therefore, the present study suggests a novel approach of initially identifying the preferred food of patients with cancer in palliative care settings. This approach is the use of a patient- 
specific nutritional plan that considers the cultural and ethical meanings of foods and their nutritional values, and the most important part is the food preference of the patients. A review on nutrition in patients with cancer emphasized the importance of a patient-specific nutrition plan approach (12). The subject is covered in the ESPEN guide published in 2017 (13). Subsequent studies are expected to develop a nutritionally rich food built on a culturally acknowledged diet. This approach could help these patients overcome at least some of the nutritional problems encountered in the course of their disease.

\section{Study Limitations}

The study limitations include the single-center setting and the small number of patients. Similarly, the nature of the food preferences makes the study more local than universal. However, this weakness could be considered a study strength because this emphasizes the cultural aspects of palliative care.

\section{Conclusion}

In conclusion, Hippocratic aphorisms regarding "food as medicine" should be considered for these patients during nutrition management in palliative care settings. This study shows the nutritional preferences of patients in palliative care. We recommend starting enteral nutrition products early to avoid malnutrition. Subsequent studies should examine the nutritional value of enriched foods and their impact on patient feeding.

\section{Ethics}

Ethics Committee Approval: Ethical committee approval was obtained before the study (16-KAEK-088).

\section{Informed Consent:}

Peer-review: Externally peer reviewed.

\section{Authorship Contributions}

Concept: N.Y.Ç., İ.O., M.S., Design: N.Y.Ç., İ.O., M.S., Data Collection or Processing: N.Y.Ç., U.Ü., R.Ç., Y.Ö., Analysis or Interpretation: R.Ç., Y.Ö., Literature Search: U.Ü., N.Y.Ç., M.S., Writing: U.Ü.

Conflict of Interest: No conflict of interest was declared by the authors.

Financial Disclosure: The authors declared that this study received no financial support.

\section{References}

1. Enig B, Petersen HN, Smith DF, Larsen B. Food preferences, nutrient intake and nutritional status in cancer patients. Acta Oncol 1987;26:301-5.

2. Bernhardson BM, Tishelman C, Rutqvist LE. Chemosensory changes experienced by patients undergoing cancer chemotherapy: a qualitative interview study. J Pain Symptom Manage 2007;34:40312.

3. Barrera R. Nutritional support in cancer patients. JPEN J Parenter Enteral Nutr 2002;26(5 Suppl):S63-71.

4. Danhauer SC, Keim J, Hurt G, Vitolins M. A survey of cancer patient preferences: which types of snacks do they prefer during treatment? Eur J Cancer Care (Engl) 2009;18:37-42.

5. Yilmaz B, Erdem D, Kemal Y. Nutrition Support Treatment in Cancer. İç Hastalıkları Dergisi 2011;18:133-43.

6. McQuestion M, Fitch M, Howell D. The changed meaning of food: Physical, social and emotional loss for patients having received radiation treatment for head and neck cancer. Eur J Oncol Nurs 2011;15:145-51.

7. Bernhardson BM, Olson K, Baracos VE, Wismer WV. Reframing eating during chemotherapy in cancer patients with chemosensory alterations. Eur J Oncol Nurs 2012;16:483-90.

8. Hutton JL, Baracos VE, Wismer WV. Chemosensory dysfunction is a primary factor in the evolution of declining nutritional status and quality of life in patients with advanced cancer. J Pain Symptom Manage 2007;33:156-65.

9. Brisbois TD, de Kock IH, Watanabe SM, Baracos VE, Wismer WV. Characterization of chemosensory alterations in advanced cancer reveals specific chemosensory phenotypes impacting dietary intake and quality of life. J Pain Symptom Manage 2011;41:673-83.

10. Bernhardson BM, Tishelman C, Rutqvist LE. Self-reported taste and smell changes during cancer chemotherapy. Support Care Cancer 2008;16:275-83.

11. Bernhardson BM, Tishelman C, Rutqvist LE. Olfactory changes among patients receiving chemotherapy. Eur J Oncol Nurs 2009;13:9-15.

12. Muhsiroglu O. Medical nutrition treatment in cancer patients. Gülhane Med J 2017;59:79-88.

13. Arends J, Bachmann P, Baracos V, Barthelemy N, Bertz H, Bozzetti F, et al. ESPEN guidelines on nutrition in cancer patients. Clin Nutr 2017;36:11-48. 